\title{
Shaping Multi-Level Energy and Climate Policy within the SET Plan Framework
}

\author{
Mattia Manni ${ }^{1, *}\left(\mathbb{D}\right.$, Valentina Coccia ${ }^{1,2}$, Diletta Paoletti ${ }^{3}$, Fabio Raspadori ${ }^{3}$, Timo Ritonummi ${ }^{4}$ \\ and Franco Cotana 1,2 \\ 1 CIRIAF-Interuniversity Research Center on Pollution and Environment "Mauro Felli", \\ University of Perugia, 06125 Perugia, Italy; coccia@crbnet.it or valentina.coccia@unipg.it (V.C.); \\ cotana@crbnet.it or franco.cotana@unipg.it (F.C.) \\ 2 Department of Engineering, University of Perugia, 06125 Perugia, Italy \\ 3 Department of Political Sciences, University of Perugia, 06123 Perugia, Italy; diletta.paoletti@unipg.it (D.P.); \\ fabio.raspadori@unipg.it (F.R.) \\ 4 Energy Department, Finnish Ministry of Economic Affairs and Employment, 00023 Helsinki, Finland; \\ timo.ritonummi@tem.fi \\ * Correspondence: manni@crbnet.it
}

Received: 14 October 2020; Accepted: 12 November 2020; Published: 17 November 2020

\begin{abstract}
At the dawn of a new European Green Deal (EGD), it is necessary to reconsider the plans and actions that have characterized the European energy policies during recent decades by tuning and updating the priorities and targets. The present work moves from the systematic review of the documents, laws, and scientific studies concerning energy and climate initiatives to the analysis of the role of the Strategic Energy and Technology Plan (SET Plan) in the energy transition. Thus, the principal research question addresses the influence of the SET Plan on multi-level energy policies. To answer this, firstly, the juridical framework in which the SET Plan was instituted is provided; secondly, its correlation to the upcoming EDG is described and the targets identified by each Implementation Working Group (IWG) are discussed. Such a dissertation is followed by the investigation of the activities at various levels from the IWG on Renewable Fuels and Bioenergy. The study has confirmed that the SET Plan contributed to shaping the energy and climate policy at European, national, and regional levels by implementing synergies among different levels of governance, different sectors, and various stakeholders (both public and private). Furthermore, it eased the sharing of data on flagship projects by periodically monitoring the achieved results.
\end{abstract}

Keywords: energy and climate policy; sustainable development; decision-making support; renewable fuels; bioenergy

\section{Introduction}

The European Commission (EC) has set ambitious targets to face climate change effects in the next future. The share of $32 \%$ of renewable energy in gross final energy consumption is expected to be achieved by 2030 together with the 32\% improvement in energy efficiency and the $40 \%$ reduction in greenhouse gas (GHG) emissions [1]. Alongside these, the EC has agreed to make efforts to keep the increment of global temperature below the $2{ }^{\circ} \mathrm{C}$ threshold while reducing GHG emissions by at least $80 \%$, by 2050 . Improving research and innovation (R\&I) performances rapidly became an essential pillar to meet such goals. It led Junker Commission to constitute the Energy Union Strategy [2], which was established to coordinate the transformation process of the European energy supply systems through the enhancement of its sustainability, secureness, and competitiveness.

Within this framework, the Strategic Energy Technology Plan (SET Plan) was endorsed to be the principal decision-making support tool for energy and climate policy [3]. The SET Plan 
represents a technology pillar of the European Union and the main platform for knowledge exchange and partnership creation. It also contributed to identifying the Energy Union R\&I priorities of intervention [4]. Significant contributions to the creation of a joint programming framework at the European level came from the European Energy Research Alliance (EERA) which worked to align the individual research organizations' priorities to those of the SET Plan.

The centrality of the SET Plan in the European energy strategy makes it necessary to investigate its functioning and priorities in order to highlight the correlations between it and the upcoming European Green Deal (EGD). This work aims at presenting an overview of the SET Plan Implementation Plans (IPs) and their targets, and also the main topics from the 2018-2023 Agenda. The analysis of the experience of the 8th Implementation Working Group (Renewable Fuels and Bioenergy IP8) and its impacts on both national and regional energy policies is then reported alongside the list of the major flagship projects (identified by IP members). The overall objective is to provide an overview of these European platforms as well as a summary of the energy-related initiatives promoted at various levels. This would contribute to strengthening the background of future research activities.

The paper is structured in the following sections: a Background section (Section 2) describing the juridical context in which SET Plan operates; a Method and design section (Section 3) explaining the methodology followed in this review study; a section entitled "SET Plan contribution to European energy policy" (Section 4) where the synergies between SET Plan and the energy initiatives, particularly the upcoming European Green Deal, are described (Section 4.1) together with the correlation between the SET Plan Key Actions and the Energy Union R\&I priorities (Section 4.2), and the SET Plan Agenda 2018-2023 (Section 4.3); an overview of the topics and objectives of the different Implementation Plans (Section 5); a section on the Renewable Fuels and Bioenergy IP8 experience and its influences at different levels (Section 6); and a conclusions section (Section 7) where the main findings are summarized and future developments described.

\section{Background: The Juridical Context of SET Plan}

Addressing the issue of the SET Plan and its potential impacts at the territorial level entails the need to outline the related juridical framework. The Plan falls within the context of the European Union's energy actions. These actions derive their legitimacy from the Title XXI of the Treaty on the Functioning of the European Union (TFEU) [5].

The articulation of EU and national competences are governed by the so-called system of competences, within which the attribution principle operates: the EU acts exclusively within the limits of the competencies that are attributed to it in the EU Treaties [5]. The action carried out in Brussels can take on different degrees of intensity: in the case of exclusive competences, only the EU can legislate on some matters that the Treaties expressly attribute to it, while in the case of complementary or support competences, the EU intervenes only to carry out coordination and completion actions concerning what the Member States (MSs) have accomplished. Halfway, there are concurrent competences, those matters about which both the EU and the MSs can take measures (but MSs can only adopt provisions if the EU has not effectively exercised its competence). Energy matter ranks among the competencies shared between the Union and the MSs, along with other principal areas such as internal market, transport, and consumer protection. Moreover, the energy area has received a relatively recent formalization in the founding Treaties: it has been the Lisbon Treaty (signed in 2007 and entered into force in 2009) [6] to introduce, among other subjects, also the "energy" among Brussels competencies.

In 2007, the political input of the European leaders kicked off and indicated the need for an integrated approach to energy and climate policy to counteract climate change effects, increase the security of energy supplies, and strengthen competitiveness. In the same year, such a political direction was implemented by the European Commission through the Communication "An Energy Policy for Europe" [7]. This designed the emerging EU interventions in the energy field. It consisted of an act of guidance and solicitation, so it was neither binding nor operative. However, a roadmap was determined together with different measures, both normative and programmatic. 
Consequently, the European Commission proposed a package of binding acts in 2008 for the achievement of the set targets. In 2009, the "Climate and Energy Package" [8] was also adopted to outline the three main European objectives: a 20\% reduction in GHG emissions (from 1990 levels), $20 \%$ of energy from renewables, and a $20 \%$ improvement in energy efficiency. Such goals converged into the climate and energy target described in the Framework Communication from the European Commission concerning the strategy for smart, sustainable, and inclusive growth for 2020 [9]. In 2011, the "Energy Road map 2050" [10] was defined, which the European Union undertook to reduce GHG emissions by $80-95 \%$ by 2050 (compared to 1990 levels). Four pathways were selected by this act such as (i) de-carbonizing the energy system, (ii) increasing the share of renewable energy and using energy more efficiently, (iii) opting for low-carbon infrastructures, and (iv) developing a European approach compared to individual national schemes (a common energy market).

A further step was taken with the "Framework for climate and energy 2030", which was established in the act "A policy framework for climate and energy in the period from 2020 to 2030" [11] and corroborated by the agreement achieved at the European Council held in October 2014 [12]. The objectives previously set for 2020 were thus updated and made more ambitious: it is expected to reach a 40\% reduction in GHG emissions (from 1990 levels) by 2030, a share of 27\% of energy from renewables, and a $27 \%$ improvement in energy efficiency.

A crucial milestone in this path is represented by the aforementioned Energy Union (2015) that was contained in the Communication from the European Commission "Framework Strategy for a Resilient Energy Union with a Forward-Looking Climate Change Policy" [13]. This new act creates a European Union Strategy with five mutually reinforcing and closely interrelated dimensions designed to bring greater energy security, sustainability, and competitiveness.

Furthermore, it is worth mentioning the Paris Agreement which was adopted in 2015 at the Paris Climate Conference (COP21) [14], in the framework United Nations Framework Convention on Climate Change (UNFCCC). This is the first-ever universal, legally binding global climate change agreement. It aims at holding the increase in the global average temperature to well below $2{ }^{\circ} \mathrm{C}$ above pre-industrial levels and pursuing efforts to limit the temperature increase to $1.5^{\circ} \mathrm{C}$ above pre-industrial levels, recognizing that this would significantly reduce the risks and impacts of climate change [14]. The Paris Agreement is perhaps the point of maturation of "mitigation" and "adaptation" concepts when applied to international and EU energy-environmental policies. The former refers to the need to reduce as much as possible (and eventually avoid) human interference with the climate system. The latter concerns the need to adapt to climate change phenomena already underway by facing the unavoidable impacts and acting considering the current or future climate characteristics.

\section{Methods and Design}

The reviewing methodology which characterizes this work followed a systematic approach [15]. Such a systematic review method allows a list of strategically selected published research studies to be gathered and critically assessed to both consolidate outputs and highlight eventual knowledge gaps. Differently from the literature review, the systematic review minimizes random errors by defining in advance the scientific question to be addressed as well as the specific inclusion and exclusion criteria for the selection of reviewed studies.

The research question which is addressed by this review work is the following one: To which extent have SET Plan activities contributed to multi-level initiatives concerning energy policies?

Therefore, the following sub-questions were outlined:

(i) How is the SET Plan influencing the upcoming European actions in the energy field?

(ii) Which are the targets identified by the SET Plan working groups for the different technologies?

(iii) How did the IWG8 on renewable fuels and bioenergy operate on multi-level governance (from regional to Italian, to European) to achieve its objectives? 
The web search engines exploited to conduct the research task were Scopus and Web of Science. These allowed the analysis of articles from scientific journals that are related to the aforementioned research questions. Furthermore, the archive of the European Commission as well as the Strategic Energy Technologies Information System (SETIS) web page were accessed to view governmental documents, international treaties, and official reports. The research activity was carried out between June 2020 and November 2020.

When it came to web search engines, the selection of the scientific articles was conducted by searching for specific terms that also appear within the research questions such as "SET Plan", "energy", and "policy". The Boolean operator "AND" was used to combine them. A three-stage screening procedure was followed. The abstract was firstly analyzed, then the results and the critical discussion were evaluated. Finally, the references were read for identifying further research studies to be included in the review.

As far as the government documents are concerned, the review process moved from the official reports from SET Plan activities towards the treaties and laws to which they referred. Additionally, the expertise of the authors as well as their knowledge of the field permitted the inclusion of, in the present work, some documents which do not appear neither on SET Plan reports nor in the other examined treaties and laws.

\section{SET Plan Contribution to European Energy Policy}

\subsection{Towards the New European Green Deal}

The SET Plan perfectly fits into the evolution of the European energy policy which is outlined in the Background section. Since 2007, Europe has identified a strategic approach to innovation for speeding up the energy transition, which was also capable of dealing with both energy supply necessities and their potential environmental negative consequences [16]. Nonetheless, Michalena [17] highlighted the lack of policy support in the European 2020 Climate and Energy Package for dealing with the complexity and multiplicity of issues associated with the local implementation of renewable energy projects: European directives were so focused on de-carbonization targets that they failed to address most of the issues observed in the National Renewable Energy Action Plans (NREAPs). Similarly, other studies investigated the effectiveness of the European energy policy through different methodologies. The Threat-Opportunity-Weakness-Strength (TOWS) matrix was applied to the renewable energy legislation in [18], while two possible pathways for carbon emission reduction were proposed by Montenegro [19] after the evaluation of competitiveness, carbon leakage, and Gross Domestic Product (GDP) growth parameters. A multi-criteria approach for group decision-making to evaluate alternative transformation pathways for achieving de-carbonization in Europe was also presented in [20]. The Energy Performance Contract was proposed by Murafa [21] to optimize the communication between public authorities and private beneficiaries, implementing evidence-based policy planning, and improving the capacity for impact assessment from the public authorities. Gnokis [22] highlighted the importance of enhancing the public-private cooperation to increase the cost-effectiveness of the adopted measures. The systematic literature review carried out by Lammers [23] concerning the institutional setting of local renewable energy planning and implementation in Europe underlined that local governments involved in most of the projects are passive observers. These generally pretend to establish ambitious climate policies and energy efficiency targets but expect other actors to engage in actions and invest. Furthermore, the subsidies were revealed to have a positive influence on the payback time, on the one hand, while they limit the upscaling the technology progress, on the other hand.

Following this, some indications were provided in $[18,24,25]$ for improving the effectiveness of European energy policy (and SET Plan activities as well) such as setting technology targets and providing specific directives for planning and prioritization of strategies to foster de-carbonization. The promotion of a comprehensive approach across different technology sectors was suggested: the relevancy of 
trans-sectoral approaches and synergies was discussed in [26,27] through the comparative analysis of national case studies and the application of JRC-EU-TIMES models.

Achievements from these studies (see Table 1) have contributed to the further enhancement of the SET Plan, making it capable of involving national governments, industries, and research actors (up to 154 umbrella organizations representing 16,700 entities) in the energy transition process through widely participatory procedures. Similarly, the SET Plan can contribute to the new European Green Deal (EGD) in the next years. The brand-new growth strategy for making the European Union a competitive society that is endowed with a modern and efficient economy, particularly in the exploitation of energy resources field. Although the EGD is still a political commitment waiting to be translated into legally binding, it is an integral part of the European Commission's strategy to implement the wider United Nation's 2030 Agenda as well as the Sustainable Development Goals (SDGs). Strong references to the key role of the Energy sector can be easily found in the EGD: "to deliver the European Green Deal, there is a need to rethink policies for clean energy supply across the economy, industry, production and consumption, large-scale infrastructure, transport, food and agriculture, construction, taxation and social benefits". Up to four main pillars such as (i) carbon pricing, (ii) sustainable investment, (iii) a new industrial policy, and (iv) a just transition have been identified by the EGD to boost the transition towards a new economic system and an energy and industrial transition. Despite the coronavirus pandemic and the consequent health crisis which rapidly turned into the global economic one, these actions to counteract climate change effects still play a relevant role in the reshaped priorities for policymakers. However, MSs are not characterized by the same starting point in the path towards the transition to carbon neutrality. Greenhouse gas performance evaluation conducted by Zlaugotne [28] revealed how the best performance level can be observed in Sweden while the worst in Latvia. A tool for planning the implementation of policies to reach EGD settings at European and national levels was also developed and presented in this research study.

Within this framework, the EGD may take advantage of the SET Plan in at least three of the four identified pillars. The SET Plan can be the principal European platform to be exploited for the definition of a shared energy implementation plan and the orientation of the technological growth of the different Countries. Its contribution may concern the definition of a common strategy when it comes to the extension of the European Emissions Trading System (EETS) to new sectors (first pillar) in order to avoid the risk of industrial delocalization into countries with less strict carbon rules. Additionally, the full mobilization of the industry, which is necessary to make efficient and sustainable investments (second pillar) in the energy and transport sector, may be coordinated through the SET Plan platform. Finally, the new industrial strategy (third pillar) needs to be outlined in a coordinated and synergic way among member countries in order to avoid overlapping. Building up synergies among the different MSs and IPs is also one of the pillars of the SET Plan working methodology. Thus, the experience achieved through the SET Plan may provide a relevant contribution to this.

Table 1. List of the scientific contributions (reverse chronological order) selected by following the systematic approach described in Section 3.

\begin{tabular}{cccl}
\hline Reference & Year & Typology & \multicolumn{1}{c}{ Scope of the Work } \\
\hline$[27]$ & 2020 & Research paper & $\begin{array}{l}\text { Modeling cross-sectoral interconnections in a } \\
\text { long-term perspective }\end{array}$ \\
\hline$[22]$ & 2020 & Research paper & $\begin{array}{l}\text { Developing a multi-perspective method to evaluate the efficiency } \\
\text { of the energy policies at the national level }\end{array}$ \\
\hline$[28]$ & 2020 & Research paper & $\begin{array}{l}\text { Analyzing different starting points (in terms of carbon emissions) } \\
\text { of the transition to carbon neutrality }\end{array}$ \\
\hline$[20]$ & 2019 & Research paper & $\begin{array}{l}\text { Implementation of a multi-criteria approach to compare } \\
\text { alternative de-carbonization pathways in Europe }\end{array}$ \\
\hline$[26]$ & 2018 & Research paper & $\begin{array}{l}\text { Reporting about lessons learned from a comparative analysis of } \\
\text { outstanding case studies }\end{array}$ \\
\hline
\end{tabular}


Table 1. Cont.

\begin{tabular}{ccll}
\hline Reference & Year & Typology & \multicolumn{1}{c}{ Scope of the Work } \\
\hline$[23]$ & 2018 & Review article & $\begin{array}{l}\text { Analyzing the institutional setting of local renewable energy } \\
\text { planning and implementation in Europe }\end{array}$ \\
\hline$[21]$ & 2017 & Research paper & $\begin{array}{l}\text { Implementing the Energy Performance Contract to regulate the } \\
\text { public-private interaction }\end{array}$ \\
\hline$[19]$ & 2017 & Research paper & $\begin{array}{l}\text { Determining pathways for carbon emission reduction through } \\
\text { multi-criteria assessment }\end{array}$ \\
\hline$[25]$ & 2016 & Research paper & $\begin{array}{l}\text { Identifying and evaluating a roadmap for achieving } \\
\text { de-carbonization until 2050 }\end{array}$ \\
\hline$[18]$ & 2016 & Research paper & $\begin{array}{l}\text { Assessing internal strengths and weaknesses of European } \\
\text { renewable energy policies and external threats and opportunities }\end{array}$ \\
\hline$[24]$ & 2014 & Research paper & $\begin{array}{l}\text { Outlining a revised SET Plan which is cross-sectoral and more } \\
\text { technology-specific focused }\end{array}$ \\
\hline$[17]$ & 2012 & Research study & $\begin{array}{l}\text { Investigating the "missing link" between the European 2020 } \\
\text { Climate and Energy Package and local renewable energy } \\
\text { projects issues }\end{array}$ \\
\hline
\end{tabular}

\subsection{SET Plan Key Actions and the Energy Union REI Priorities}

Up to 10 SET Plan Key Actions were determined according to Energy Union R\&I priorities (Table 2). National governments, companies, and research institutions set different targets for each priority point. Such actors were clustered into 13 Implementation Working Groups (IWGs) to cooperate in the definition of the Implementation Plans (IPs) with concrete actions to be proposed and agreed upon. IPs aim at sustaining technological leadership in renewables, implementing a smart consumer-centric energy system, developing and strengthening energy-efficient systems, determining energy options for sustainable transport systems, and promoting carbon capture utilization and storage. The SET Plan has accelerated the development and deployment of low-carbon technologies by enhancing new solutions and bringing down their costs. It is finalized to promote innovation partnerships across Europe and to support the most impactful technologies that could contribute to the de-carbonization of the European energy system in the near future.

Table 2. Overview of the European energy priorities expressed as SET Plan Key Actions, Implementation Plans, and Energy Union research and innovation (R\&I) Priorities.

\begin{tabular}{|c|c|c|}
\hline Key Actions & Implementation Plans & Energy Union R\&I Priorities \\
\hline $\begin{array}{l}\text { Performant renewable } \\
\text { technologies integrated into } \\
\text { the system } \\
\text { - Reduce costs of } \\
\text { key technologies }\end{array}$ & $\begin{array}{ll}\text { - } & \text { Solar Photovoltaic IP } \\
\text { - } & \text { Solar Thermal Electricity and } \\
& \text { Concentrated Solar Power IP } \\
\text { - } & \text { Offshore Wind IP } \\
\text { - } & \text { Ocean Energy IP } \\
\text { - } & \text { Deep Geothermal IP }\end{array}$ & $\begin{array}{l}\text { - Core priority: Technological } \\
\text { leadership in renewables }\end{array}$ \\
\hline $\begin{array}{l}\text { - Create technologies and } \\
\text { services for smart } \\
\text { energy consumers } \\
\text { Resilience, security, } \\
\text { and smartness of the } \\
\text { energy system }\end{array}$ & $\begin{array}{ll}\text { - } & \text { Smart Solutions for Energy } \\
\text { - } & \text { Consumers IP } \\
\text { Towards Positive Energy } \\
\text { Districts for Sustainable } \\
\text { Urbanization IP } \\
\text { - } \quad \text { Energy Systems IP }\end{array}$ & $\begin{array}{l}\text { - Core priority: Smart } \\
\text { consumer-centric } \\
\text { energy system }\end{array}$ \\
\hline $\begin{array}{l}\text { - New materials and } \\
\text { technologies for buildings } \\
\text { Energy efficiency } \\
\text { for industries }\end{array}$ & $\begin{array}{l}\text { - } \quad \text { Energy efficiency in buildings } \\
\text { - } \quad \text { Energy efficiency in industry }\end{array}$ & $\begin{array}{l}\text { - Core priority: Efficient } \\
\text { energy systems }\end{array}$ \\
\hline
\end{tabular}


Table 2. Cont.

\begin{tabular}{|c|c|c|}
\hline Key Actions & Implementation Plans & Energy Union R\&I Priorities \\
\hline $\begin{array}{l}\text { - } \quad \text { Competitive in global battery } \\
\text { sector (e-mobility) } \\
\text { - } \quad \text { Renewable fuels }\end{array}$ & $\begin{array}{l}\text { - } \quad \text { Batteries for e-Mobility and } \\
\text { Stationary Storage IP } \\
\text { - } \quad \text { Renewable Fuels and } \\
\text { Bioenergy IP }\end{array}$ & $\begin{array}{l}\text { - Core priority: } \\
\text { Sustainable transport }\end{array}$ \\
\hline $\begin{array}{l}\text { Carbon capture utilization } \\
\text { and storage }\end{array}$ & $\begin{array}{l}\text { - Carbon Capture Utilization } \\
\text { and Storage IP }\end{array}$ & $\begin{array}{l}\text { Additional priority: Driving } \\
\text { ambition in carbon capture } \\
\text { storage and use }\end{array}$ \\
\hline - Nuclear safety & - & $\begin{array}{l}\text { - Additional priority: Increase } \\
\text { safety in nuclear energy }\end{array}$ \\
\hline
\end{tabular}

\subsection{SET Plan Agenda 2018-2023}

The SET Plan Agenda 2018-2023 proposes relevant tasks for implementing the SET Plan Key Actions over the upcoming five years. In particular, tasks are embedded in three chapters: (i) implementation, (ii) funding of activities, and (iii) institutional strengthening and outreach.

Firstly, implementation-related activities include progress monitoring of the actions under the different IPs and feeding such information to the Strategic Energy Technology Information System (SETIS). The execution of each IP is ensured by involving all relevant stakeholders in the activities of the corresponding IWG. Each IWG enables, promotes, facilitates, and monitors the execution of the identified R\&I activities. However, the Agenda pointed out the risk that these groups could become many closed clubs, while relevant actors should always be able to join the groups. Furthermore, the Agenda stated that the work of the IWGs and the IPs should be continuously evolving to match the sectoral developments. In that regard, a cluster of indicators following the National Energy and Climate Plans (NECPs) may be proposed. Additionally, each IWG has to identify eventual cross-cutting dimensions to avoid overlapping activities as well as to develop synergies with other IPs. This contributes to increasing the overall impact and reducing the global costs.

Secondly, funding tasks refer to co-programming and coordination activities at various levels for orienting and aligning the different funding calls. In the Agenda, the importance of identifying the most suitable funding mechanisms and opportunities to implement the 10 Key Actions has been underlined. In particular, each IWG is responsible for the coordination between public funding at the level of the European Union, SET Plan countries, and regions. Determining such synergies is fundamental for setting-up some transnational funding schemes and mobilizing consistent investments. The Agenda refers to this mechanism as a "map and match" strategy which aims at "mapping" the interests and capacities of stakeholders and "matching" them with actual funding opportunities.

Thirdly, institutional strengthening and outreach tasks concern community involvement, visibility, and dissemination of achieved results. The programmatic document invites the MSs to adapt to a new governance model by 2021 to implement energy and climate policies according to the Regulation of the Energy Union Governance. In parallel, they have to report regularly on their national R\&I objectives and associated strategies. The NECPs can help in identifying adequate methodologies (see the aforementioned indicators) to make this process systematic and relate it to SET Plan progress. Furthermore, SET Plan countries and the EC intend to develop synergies between IPs and remarkable international initiatives such as Innovation Challenges (ICs) of Mission Innovation (MI) for strengthening the impact of the achievements and enhancing their visibility. For example, R\&I activities concerning smart grids, carbon capture, sustainable biofuels, and affordable heating and cooling buildings from MI perfectly match with IPs on energy systems, carbon capture and storage, renewable fuels and bioenergy, and energy efficiency solutions for buildings. When it comes to the communication strategy, the main objectives refer to informing key stakeholders on progress and achievements, increasing the prominence of the SET Plan as a key dimension of the Energy Union, 
cooperating with decision-makers in SET Plan countries to align R\&I activities, disseminating results and showcase successes, and reaching out to international audiences to support the energy transition.

\section{Implementation Plans}

Implementation Plans are finalized to the enhancement of the EU energy system and they can be grouped based on their aims and technology sectors. In particular, five clusters corresponding to the Energy Union R\&I priorities were identified: Solar Photovoltaic IP, Concentrated Solar Power (or Solar Thermal Electricity) IP, Offshore Wind Energy IP, Deep Geothermal Energy IP, and Ocean Energy IP should permit the technological leadership in renewables to be sustained; Smart Solutions for Energy Consumers IP, Towards Positive Energy Districts for Sustainable Urbanization IP, and Energy Systems IP are included in the cluster pointing at implementing a smart consumer-centric energy system; Energy Efficiency in Buildings IP and Energy Efficiency in Industry IP will lead to the development and strengthening of energy-efficient systems; Batteries for e-Mobility and Stationary Storage IP, and Renewable Fuels and Bioenergy IP8 allow the identification of energy options for sustainable transport systems. Alongside these, there is also the Carbon Capture Utilization and Storage IP whose field of investigation represents the core of an additional Energy Union R\&I priority. Ongoing R\&I activities were mapped for each IP based on the defined targets, then actions and flagship projects were identified.

When it comes to technological leadership in renewables, IPs focus on the implementation of advanced building-integrated photovoltaic application, the realization of a concentrated solar thermal power plant, the development and optimization of interconnections among offshore wind energy grids, the integration of the geothermal energy source with other RES, and the definition of guidelines, standards, and certification protocols for tidal and wave energy. In particular, Europe is a world leader in ocean energy, and high-level activities for tidal and wave energy are assessed in the Ocean energy IP.

A smart consumer-centric energy system is the pursuit by permitting access to different sources of data and offering real-time monitoring control. New ideas, solutions, and services will be carried out to support the replication of the pilot projects on positive energy districts for sustainable urbanization which are currently monitored. Additionally, developing and optimizing the European power grid as well as integrating local and regional energy systems is considered as a fundamental step to completely implement this Energy Union priority.

The aims are the development and strengthening of energy-efficient systems through the enhancement of energy efficiency in buildings and industry. Such IPs focus on improving heating and cooling technologies while reducing primary energy demand. In particular, most of the actions concerning industry address the steel and iron sector, together with chemical and pharma.

When referring to sustainable transport, R\&I actions are mainly related to e-mobility batteries and renewable fuels. On the one hand, the European Battery Alliance is working on the development of battery manufacturing, since Europe currently produces less than $1 \%$ of global Li-ion battery cells. On the other hand, advanced biofuels for transport, other renewable fuels of non-biological origin, intermediate bioenergy carriers, renewable hydrogen, and large-scale biomass combined heat and power are investigated and promoted.

Finally, carbon capture utilization and storage represent an important set of technologies for the de-carbonization of power generation and energy-intensive industries.

The principal targets set by each IP are shown in Table 3 and mainly address the improvement of the efficiency, the reduction in the costs, and the extension of the technologies' lifetimes. They also refer to the enhancement of sustainability through the mitigation of GHG emissions, and the realization of a demonstration project (i.e., concentrated solar power, positive energy districts). The leveled cost of energy is expected to be decreased when it comes to implementing renewable energy sources (i.e., offshore wind, ocean energy), while promoting step changes in performance combined with mass production (or technology spread) when referring to innovative technologies (i.e., e-mobile batteries, photovoltaic systems). 
Table 3. Implementation Plans and respective involved countries, targets, and mobilized investments.

\begin{tabular}{|c|c|c|c|}
\hline Implementation Plan & Countries & Targets & Mobilized Investments \\
\hline \multicolumn{4}{|l|}{ Technological leadership in renewables } \\
\hline Solar Photovoltaic IP & se & $\begin{array}{l}\text { By 2030: } \\
\text { - } \quad \text { Higher efficiency; } \\
\text { - } \quad \text { Cost reduction; } \\
\text { - } \quad \text { Enhancing the lifetime; } \\
\text { - } \quad \text { Advancing manufacturing. }\end{array}$ & $\begin{array}{l}\text { In total, EUR } 530 \text { million split as follows: } \\
\text { - } \quad \text { EUR } 70 \text { million from private sector; } \\
\text { - } \quad \text { EUR } 30 \text { million from EU funds; } \\
\text { - } \quad \text { EUR } 430 \text { million from national programs. }\end{array}$ \\
\hline $\begin{array}{l}\text { Concentrated Solar Power/Solar } \\
\text { Thermal Electricity IP }\end{array}$ & & $\begin{array}{l}\text { By 2020: } \\
\text { - } \quad 40 \% \text { cost reduction; } \\
\text { - } \quad \text { New cycles with a first demonstration } \\
\quad \text { project ready. }\end{array}$ & $\begin{array}{l}\text { In total, EUR } 200 \text { million split as follows: } \\
\text { - } \quad \text { EUR } 100 \text { million from private sector; } \\
\text { - } \quad \text { EUR } 95 \text { million from EU funds; } \\
\text { - } \quad \text { EUR } 5 \text { million from national programs. } \\
\text { The first demonstration project requires up to } \\
\text { EUR } 1 \text { billion in addition. }\end{array}$ \\
\hline Offshore Wind Energy IP & & $\begin{array}{l}\text { Reducing the levelized cost of energy (LCOE) to } \\
\text { less than: } \\
\text { - } \quad 12 \mathrm{EUR} / \mathrm{kWh} \text { by } 2025 \text {; } \\
\text { - } \quad 9 \mathrm{EUR} / \mathrm{kWh} \text { by } 2030 \text {. }\end{array}$ & $\begin{array}{l}\text { In total, EUR 1,090 million split as follows: } \\
\text { - } \quad \text { EUR } 375 \text { million from private sector; } \\
\text { - } \quad \text { EUR } 268 \text { million from EU funds; } \\
\text { - } \quad \text { EUR } 446 \text { million from national programs. }\end{array}$ \\
\hline Deep Geothermal Energy IP & 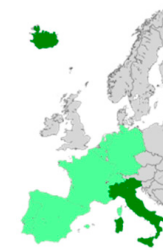 & $\begin{array}{l}\text { - Reducing exploration costs by } 25 \% \text { in } 2025 \text {, } \\
\text { and by } 50 \% \text { in } 2050 \text {; } \\
\text { Reducing unit cost of drilling by } 15 \% \text { in } \\
2020,30 \% \text { in } 2030 \text {, and } 50 \% \text { in } 2050 \text {; } \\
\text { - Limiting up and down from } 60-110 \% \text { of } \\
\text { nominal power. }\end{array}$ & $\begin{array}{l}\text { In total, EUR } 936.5 \text { million split as follows: } \\
\text { - } \quad \text { EUR } 456 \text { million from private sector; } \\
\text { - } \quad \text { EUR } 14.5 \text { million from EU funds; } \\
\text { - } \quad \text { EUR } 342 \text { million from national programs. }\end{array}$ \\
\hline
\end{tabular}


Table 3. Cont.

\begin{tabular}{|c|c|c|c|}
\hline Implementation Plan & Countries & Targets & Mobilized Investments \\
\hline Ocean Energy IP & ens & $\begin{array}{l}\text { - Reducing LCoE for tidal stream energy to } \\
\text { at least } 15 \mathrm{EUR} / \mathrm{kWh} \text { in } 2025 \text {, and } 10 \\
\text { EUR/kWh in 2030; } \\
\text { Reducing LCoE for wave energy to at least } \\
20 \mathrm{EUR} / \mathrm{kWh} \text { in } 2025,15 \mathrm{EUR} / \mathrm{kWh} \text { in } 2030 \text {, } \\
\text { and } 10 \mathrm{EUR} / \mathrm{kWh} \text { in } 2035 \text {. }\end{array}$ & $\begin{array}{l}\text { In total, EUR 1,240 million split as follows: } \\
\text { - } \quad \text { EUR } 411.5 \text { million from private sector; } \\
\text { - } \quad \text { EUR } 409.5 \text { million from EU funds; } \\
\text { - } \quad \text { EUR } 421.5 \text { million from national programs. }\end{array}$ \\
\hline \multicolumn{4}{|l|}{ Smart consumer-centric energy system } \\
\hline $\begin{array}{l}\text { Smart Solutions for Energy } \\
\text { Consumers IP }\end{array}$ & & $\begin{array}{l}\text { - Implementing interoperable } \\
\text { reference architecture; } \\
\text { Improving of electricity } \\
\text { consumption management; } \\
\text { - Reduction in costs and increased } \\
\text { penetration of users friendly tools; } \\
\text { - Controlling through ICT at least } 80 \% \text { of the } \\
\text { total energy consumption in } 80 \% \text { of the } \\
\text { homes in Europe. }\end{array}$ & $\begin{array}{l}\text { In total, EUR } 859 \text { million split as follows: } \\
\text { - } \quad \text { EUR } 781.69 \text { million from EU funds; } \\
\text { - } \quad \text { EUR } 77.31 \text { million from national programs. }\end{array}$ \\
\hline $\begin{array}{l}\text { Towards Positive Energy Districts for } \\
\text { Sustainable Urbanization IP }\end{array}$ & se & $\begin{array}{l}\text { - Supporting the planning, deployment, } \\
\text { and replication of } 100 \text { positive energy } \\
\text { districts (PEDs) for sustainable } \\
\text { urbanization by } 2025 \text {. }\end{array}$ & $\begin{array}{l}\text { In total, EUR 100,750 million split as follows: } \\
\text { - } \quad \text { EUR 30,000 million from private } \\
\text { construction investments in PEDs; } \\
\text { - } \quad \text { EUR 70,000 million from private } \\
\text { infrastructure investments in PEDs; } \\
\text { - EUR 750 million from initial IP investment } \\
\text { (public, private, and EU funds). }\end{array}$ \\
\hline
\end{tabular}


Table 3. Cont.

\begin{tabular}{|c|c|c|c|}
\hline Implementation Plan & Countries & Targets & Mobilized Investments \\
\hline Energy Systems IP & ens & $\begin{array}{l}\text { - } \quad 80 \% \text { observability of networks at high and } \\
\text { medium voltage level; } \\
\text { - } \quad 25 \% \text { peak load reduction; } \\
\text { - } 10 \% \text { improved accuracy of forecasting for } \\
\text { aggregated RES plant power production; } \\
\text { - } \quad 50-70 \% \text { reduction in specific storage costs; } \\
\text { - Beyond } 100 \% \text { RES use in the local or } \\
\text { regional supply by linking different } \\
\text { energy domains. }\end{array}$ & $\begin{array}{l}\text { In total, EUR 4,500 million split as follows: } \\
\text { - } \quad \text { EUR 2,500 million from private sector; } \\
\text { - } \quad \text { EUR 1,000 million from EU funds; } \\
\text { - } \quad \text { EUR 1,000 million from national programs. }\end{array}$ \\
\hline
\end{tabular}

Energy efficient systems

For heating and cooling by 2025 :

- $50 \%$ reduction in costs of both heat pumps and micro-combined heat and power;

- $25 \%$ increment of renewable heat in DHC

- $25 \%$ improvement of energy storage.

- For materials by 2025 .

Energy Efficiency in Buildings IP

- $60 \%$ reduction on average primary energy demand in buildings;

- At least $10 \%$ decrement in costs of nZEB or positive energy buildings (PEBs)

- $\quad$ Reducing differences between predicted and measured energy performance to at least $15 \%$.

In total, EUR 1,100 million split as follows:

- $\quad$ EUR 365 million from private sector;

- EUR 335 million from EU funds;

- EUR 400 million from national programs.

In total, EUR 3,400 million split as follows:

Energy Efficiency in Industry IP

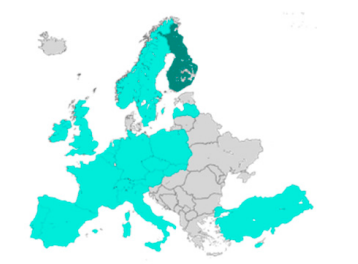

- $\quad 20 \%$ reduce energy consumption by 2025 .

- $1 / 3$ of the technical potential energy savings by 2030 .
- $\quad$ EUR 2,050 million for iron and steel sectors;

- EUR 450 million for chemical and pharma sector;

- $\quad$ EUR 550 million for system integration and symbiosis;

- EUR 350 million for heat/cold recovery. 
Table 3. Cont.

\begin{tabular}{|c|c|c|c|}
\hline Implementation Plan & Countries & Targets & Mobilized Investments \\
\hline \multicolumn{4}{|l|}{ Sustainable transportation } \\
\hline $\begin{array}{l}\text { Batteries for e-Mobility and Stationary } \\
\text { Storage IP }\end{array}$ & sh & $\begin{array}{l}\text { By 2030: } \\
\text { - } \quad \text { Energy density at cell level lower than } 350 \\
\text { - } \quad \text { Automotive battery pack cost } 75 \mathrm{EUR} / \mathrm{kWh} \text {; } \\
\text { - } \quad \text { Stationary energy storage cost } 0.05 \\
\text { EUR/kWh per cycle; } \\
\text { - } \quad \text { Automotive manufacturing } 50 \mathrm{GWh} / \text { year; } \\
\text { - } \quad \text { Stationary manufacturing } 10 \mathrm{GWh} / \text { year. }\end{array}$ & 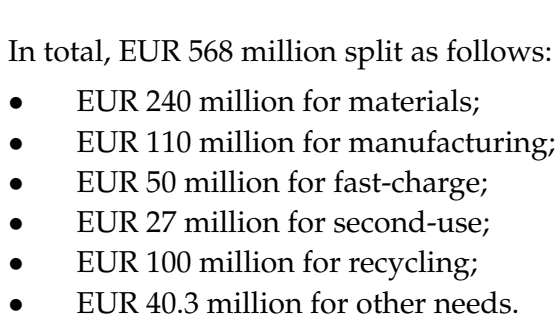 \\
\hline
\end{tabular}

By 2030:

\section{Renewable Fuels and Bioenergy IP}

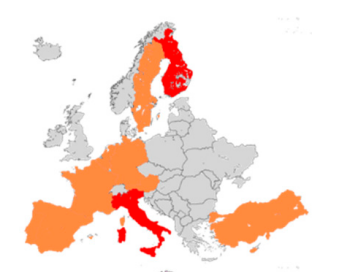

- $80 \%$ reduction in GHG emissions;

- $30 \%$ increment in performance of production;

- $20-30 \%$ reduction in conversion system costs.

By 2050 :

- $80 \%$ reduction in GHG emissions;

- $50 \%$ reduction in conversion system costs
In total, EUR 2,330 million split as follows:

- $\quad$ EUR 590 million from private sector;

- EUR 590 million from EU funds;

- EUR 1,150 million from national programs.

Carbon capture storage and use

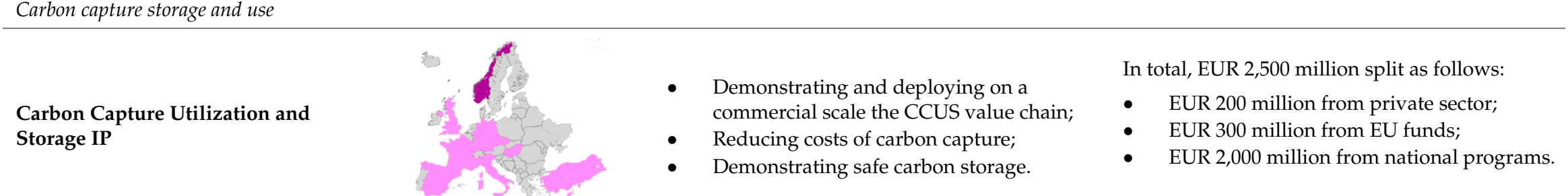




\section{Influences of Renewable Fuels and Bioenergy IP8 at Different Levels}

Among the aspects that make the SET Plan an appropriate tool to help to achieve the environmental and socio-economic objectives of the EGD consists of its multi-level structure. This approach generally characterizes the European Union's mode of action. As stated in the Resolution of the Committee of the Regions on the Charter for Multi-level Governance in Europe [29], the European multi-level governance is an approach based on coordinated action by the European Union, the MSs, and regional and local authorities according to the principles of subsidiarity, proportionality, and partnership, taking the form of operational and institutional cooperation in the drawing up and implementation of the European Union's policies. This means the European legal system constantly cooperates in relation to the national, regional, and local systems when it comes to the adoption and implementation of laws and legally binding provisions, and also to the European financing system.

According to this, the analysis of the influences of SET Plan at different levels was conducted by presenting the case study of the Renewable Fuels and Bioenergy IP8. The work carried out by IP8 permitted determining joint actions to maximize the effectiveness of contributions from the European Union and national R\&I programs. This goal was achieved by reporting regularly on the progresses to monitor the realization of the targets and correcting actions when necessary. In this context, the role of SET Plan Countries and stakeholders was to identify ongoing R\&I activities (i.e., flagships, large-scale demonstration projects) that can contribute to meeting the targets, as well as to define non-technological barriers and enablers. Among the enablers, the main ones refer to the creation of a long-term stable policy framework, the definition of well-established and agreed sustainability criteria for feedstock, the support of emerging technologies at low Technology Readiness Level (TRL), and promoting the integration of renewable fuels (and bioenergy) in different energy systems (i.e., power-to-gas, power-to-liquid). Regarding the barriers, restrictions in the current policy framework (i.e., grid fees for power-to-fuel), heavily restricted feedstock portfolio, lack of dedicated actions and policies to meet the demand for appropriate infrastructure and vehicles, and stricter view on sustainability criteria when applied to renewable fuels or bioenergy were recognized as the major ones.

Representatives of stakeholders and SET Plan Countries taking part in IWG on renewable fuels and bioenergy were asked to provide information on relevant flagship activities. A "flagship activity" is a project or program considered as the best example of what R\&I can achieve in a given sector. Thus, it is not necessarily financed by European funds nor promoted through European programs. Additionally, the flagship activities are not receiving any subsidy from the SET Plan which only guarantees them high visibility in exchange for data, updates, and information on the projects. Such ongoing R\&I activities are expected to contribute to the achievement of SET Plan targets. The innovation potential and the possibility of establishing a positive public image constitute the selection criteria. The major projects proposed by participants as flagships are reported in Figure 1.

According to the recommendations from the Renewable Fuels and Bioenergy IP8, a national working group was established in Italy in 2016. This group was composed of representatives of the main Italian stakeholders in the field of bioenergy and sustainable transport. Such actors represent the government, research institutions, and companies. Governmental delegates mainly come from the Italian Ministries for the Economic Development. The academic part of the group is composed of researchers from the Italian Energy Agency, which is the principal investigator in the bioenergy research field, and from the National Biomass Research Center (CRB Section of CIRIAF). Finally, representatives of the industrial stakeholders are employed in the most relevant Italian companies such as the Eni Group. In particular, companies have significantly contributed to the achievement of the IP objectives by managing and monitoring flagship projects. An overview of the Italian projects evaluated within the Renewable Fuels and Bioenergy IP8 activities was reported in Table 4. 


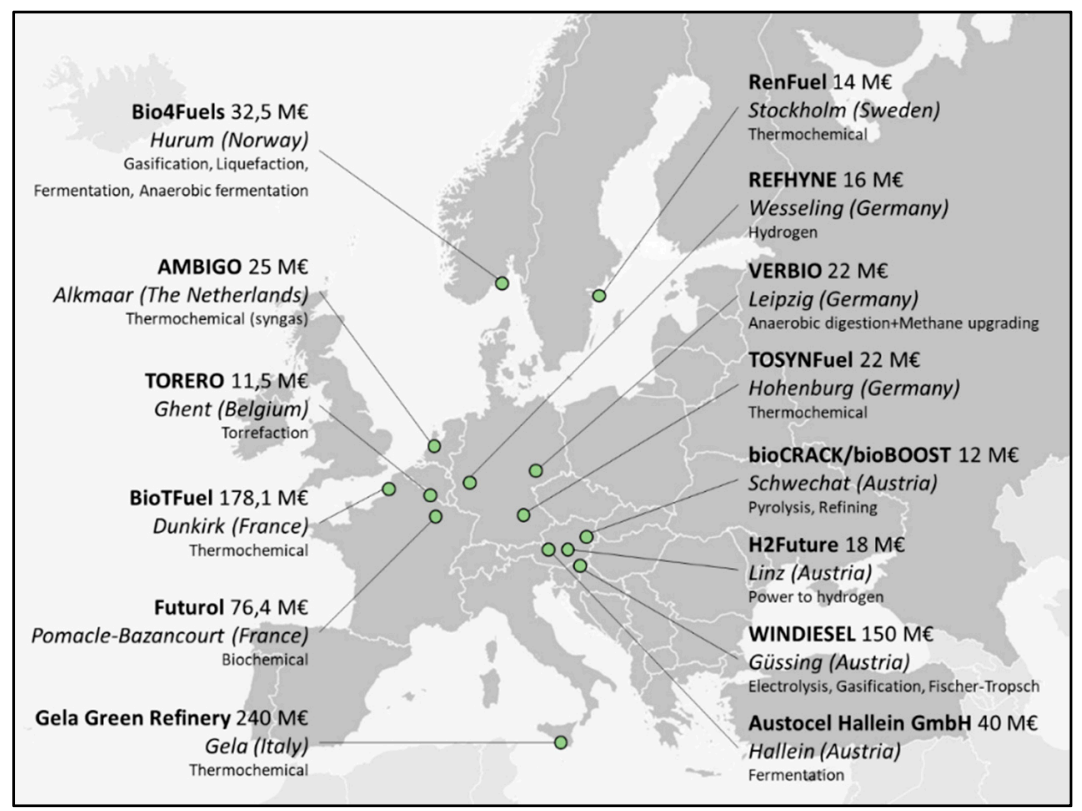

Figure 1. Main flagship projects identified by Renewable Fuels and Bioenergy IP8.

Table 4. List of Italian flagships (including budget) contributing to the objectives of the IWG8 on bioenergy and sustainable development.

\begin{tabular}{|c|c|c|}
\hline Project NAME & Short Description & $\begin{array}{l}\text { Budget } \\
\text { [M EUR] }\end{array}$ \\
\hline Gela Green Refinery & $\begin{array}{l}\text { Advanced liquid biofuels } \\
\text { Thermochemical processes }\end{array}$ & 240 \\
\hline Eni Refinery & $\begin{array}{l}\text { Advanced liquid biofuels } \\
\text { Thermochemical processes: hydro-treatment }\end{array}$ & 2 \\
\hline Eni Refinery * & $\begin{array}{l}\text { Advanced liquid biofuels } \\
\text { Thermochemical processes: hydro-treatment }\end{array}$ & 4 \\
\hline Eni Refinery & $\begin{array}{c}\text { Advanced liquid biofuels } \\
\text { Biochemical processes: microbial fermentation and } \\
\text { hydro-treatment }\end{array}$ & 4 \\
\hline $\mathrm{CO}_{2}$ Bio-fixation Incubator Plant & $\begin{array}{l}\text { Algae-based Fuels } \\
\text { Lipid accumulation }\end{array}$ & 6 \\
\hline $\begin{array}{l}\text { WASTE TO FUEL } \\
\text { Gela Refinery }\end{array}$ & $\begin{array}{l}\text { Intermediate bioenergy carriers } \\
\text { Hydrothermal liquefaction }\end{array}$ & 10 \\
\hline
\end{tabular}

By 2030, such flagship projects are expected to improve the net process efficiency of production pathways of advanced renewable liquid and gaseous fuels by at least $30 \%$ (compared to present values). Additionally, the volume of GHG emissions avoided thanks to the utilization of these advanced renewable fuels has to be reduced by $60 \%$. In parallel, the costs of the other renewable fuels except hydrogen should be at least halved (to less than 50 EUR/MWh excluding taxes and feedstock cost).

When it comes to regional energy and climate policy, the contribution from the IWG on renewable fuel and bioenergy consisted of a cluster of guidelines to align the objective of the Regional Strategy on Research and Innovation for Smart Specialization (RIS3) to the SET Plan targets.

\section{Conclusions}

At the dawn of the EGD, this research study highlighted the contributions of the SET Plan program, particularly the Renewable Fuels and Bioenergy IP8, to energy and climate policy at various levels. 
Potential synergies between the EGD and the SET Plan along with a description of the SET Plan Agenda 2018-2023 were pointed out. Additionally, an overview of the SET Plan Key Actions and the corresponding Energy Union R\&I priorities was presented.

The main conclusive thoughts are summarized in the following bullets for each level of governance (i.e., European, national, regional):

- At the European level, the SET Plan experience must be considered as a reference point by the upcoming EGD. The SET Plan has permitted the creation of a cross-country framework where the most promising research and innovation activities (i.e., flagship projects) can be promoted and shared, while their objectives aligned. Furthermore, the involvement of representatives from the industry which is searched by the EGD has also represented a pillar of the SET Plan activities; thus, the IWGs may also provide a relevant contribution to the upcoming Green Deal.

- At the national level, the creation of a roundtable where the principal stakeholders can provide their contributions to outline the future European energy system has represented a fundamental achievement. This is contributing to creating adequate funding opportunities for those technologies which are worth being implemented.

- At the regional level, a programmatic document about research and innovation has been compiled by the regional government in Umbria by aligning activities and objectives to the guidelines carried out by the SET Plan IWGs (and the Renewable Fuels and Bioenergy IP8, in particular).

In conclusion, the SET Plan has contributed to shaping the energy and climate policy at European, national, and regional levels by implementing synergies among the different levels of governance and the various stakeholders (i.e., government, industry, and academic representatives).

Author Contributions: Conceptualization, F.C.; methodology, M.M. and F.C.; formal analysis, V.C. and D.P.; investigation, V.C.; resources, D.P.; data curation, M.M.; writing—original draft preparation, M.M., V.C., and D.P.; writing-review and editing, F.R. and T.R.; visualization, M.M.; supervision, F.C.; project administration, F.C. and T.R. All authors have read and agreed to the published version of the manuscript.

Funding: This research received no external funding.

Acknowledgments: The authors wish to thank the members of the SET Plan IWGs, particularly the ones from the Renewable Fuels and Bioenergy IP8.

Conflicts of Interest: The authors declare no conflict of interest.

\section{References}

1. Carvalho, M.D.G. EU energy and climate change strategy. Energy 2012, 40, 19-22. [CrossRef]

2. Ringel, M.; Knodt, M. The governance of the European Energy Union: Efficiency, effectiveness and acceptance of the Winter Package 2016. Energy Policy 2018, 112, 209-220. [CrossRef]

3. EC proposes Strategic Energy Technology Plan. Fuel Cells Bull. 2008, 2008, 11. [CrossRef]

4. Soriano, F.H.; Mulatero, F. EU Research and Innovation (R\&I) in renewable energies: The role of the Strategic Energy Technology Plan (SET-Plan). Energy Policy 2011, 39, 3582-3590. [CrossRef]

5. European Union Treaties: Treaty on European Union Treaty on the Functioning of the European Union; European Union: Brussels, Belgium, 2015; pp. 1-388.

6. European Union Treaty of Lisbon; European Union:: Brussels, Belgium, 2007; pp. 1-229.

7. European Parliament and Council an Energy Policy for Europe; European Union: Brussels, Belgium, 2007.

8. European Parliament and Council Climate and Energy Package 2009; European Union: Brussels, Belgium, 2009.

9. European Commission EUROPE 2020. A Strategy for Smart, Sustainable and Inclusive Growth; European Union: Brussels, Belgium, 2010; pp. 1-37.

10. European Commission Energy Roadmap 2050; European Union: Brussels, Belgium, 2011.

11. European Commission A Policy Framework for Climate and Energy in the Period from 2020 to 2030; European Union: Brussels, Belgium, 2014.

12. European Parliament and Council Conclusions on 2030 Climate and Energy Policy Framework; European Union: Brussels, Belgium, 2014. 
13. European Commission Framework Strategy for a Resilient Energy Union with a Forward-Looking Climate Change Policy; European Union: Brussels, Belgium, 2015; pp. 1-21.

14. Warren, R.; Price, J.; Vanderwal, J.; Cornelius, S.; Sohl, H. The implications of the United Nations Paris Agreement on climate change for globally significant biodiversity areas. Clim. Chang. 2018, 147, 395-409. [CrossRef]

15. Kousis, I.; Pisello, A.L. For the mitigation of urban heat island and urban noise island: Two simultaneous sides of urban discomfort. Environ. Res. Lett. 2020, 15, 103004. [CrossRef]

16. European Commission a European Strategic Energy and Technology Plan (SET-Plan). Towards a Low-carbon Future; European Union: Brussels, Belgium, 2007; pp. 1-12.

17. Michalena, E.; Hills, J.M. Renewable energy issues and implementation of European energy policy: The missing generation? Energy Policy 2012, 45, 201-216. [CrossRef]

18. Wyns, T.; Khatchadourian, A. Situational analysis of EU renewable energy legislation. Clim. Policy 2016, 16, 568-585. [CrossRef]

19. Montenegro, R.C.; Fahl, U. Carbon leakage and competitiveness: Socio-economic impacts of greenhouse gas emissions decrease on the European area until 2050. In Proceedings of the 2017 14th International Conference on the European Energy Market (EEM), Dresden, Germany, 6-9 June 2017; Institute of Electrical and Electronics Engineers (IEEE): Piscataway, NJ, USA, 2017; pp. 1-5.

20. Papapostolou, A.; Karakosta, C.; Kourti, K.-A.; Doukas, H.; Psarras, J.E. Supporting Europe's Energy Policy Towards a Decarbonised Energy System: A Comparative Assessment. Sustainability 2019, 11, 4010. [CrossRef]

21. Murafa, C. The energy performance contract-Key towards energy efficiency in Europe? Proc. Int. Conf. Bus. Excel. 2017, 11, 103-110. [CrossRef]

22. Gkonis, N.; Arsenopoulos, A.; Stamatiou, A.; Doukas, H. Multi-perspective design of energy efficiency policies under the framework of national energy and climate action plans. Energy Policy 2020, 140, 111401. [CrossRef]

23. Lammers, I.; Hoppe, T. Analysing the Institutional Setting of Local Renewable Energy Planning and Implementation in the EU: A Systematic Literature Review. Sustainability 2018, 10, 3212. [CrossRef]

24. Ruester, S.; Schwenen, S.; Finger, M.; Glachant, J.-M. A post-2020 EU energy technology policy: Revisiting the strategic energy technology plan. Energy Policy 2014, 66, 209-217. [CrossRef]

25. Kumar, S.; Madlener, R. Renewable energy roadmap for central Europe until 2050: A scenario based techno-economic analysis. In 2016 21st Century Energy Needs-Materials, Systems and Applications (ICTFCEN); IEEE: Piscataway, NJ, USA, 2016; pp. 1-6. [CrossRef]

26. Frantal, B.; Van Der Horst, D.; Martinát, S.; Schmitz, S.; Teschner, N.; Silva, L.; Golobic, M.; Roth, M. Spatial targeting, synergies and scale: Exploring the criteria of smart practices for siting renewable energy projects. Energy Policy 2018, 120, 85-93. [CrossRef]

27. Pavičević, M.; Mangipinto, A.; Nijs, W.; Lombardi, F.; Kavvadias, K.; Navarro, J.P.J.; Colombo, E.; Quoilin, S. The potential of sector coupling in future European energy systems: Soft linking between the Dispa-SET and JRC-EU-TIMES models. Appl. Energy 2020, 267, 115100. [CrossRef]

28. Zlaugotne, B.; Ievina, L.; Azis, R.; Baranenko, D.; Blumberga, D. GHG Performance Evaluation in Green Deal Context. Environ. Clim. Technol. 2020, 24, 431-441. [CrossRef]

29. European Commission Charter for Multilevel Governance in Europe; European Union: Brussels, Belgium, 2014.

Publisher's Note: MDPI stays neutral with regard to jurisdictional claims in published maps and institutional affiliations.

(C) 2020 by the authors. Licensee MDPI, Basel, Switzerland. This article is an open access article distributed under the terms and conditions of the Creative Commons Attribution (CC BY) license (http://creativecommons.org/licenses/by/4.0/). 